\title{
Topicalizations, left dislocations and the left-periphery*
}

\author{
Bernard Bortolussi \\ Université Paris Nanterre. THEMAM, ArScAn \\ bernard.bortolussi@u-paris10.fr
}

Received: February 4, 2017

Accepted: July 17, 2017

\begin{abstract}
My intention in this paper is to provide as complete an overview as possible of the different types of topic phrases in Latin. After setting out the characteristics and properties of what I call Dislocations (Hanging Topics and CILD) and Topicalizations, I go on to give a description of each morphological or syntactic device employed in Latin: prepositional DP, case marking, fronting clauses. I then propose a hypothesis concerning the cartography of the left periphery in Latin. In addition, I introduce a brief description of an original way of topicalizing the subjects of embedded clauses, namely proleptic accusative construction. The main conclusion is that the cartography of Latin left periphery is not very different from that to be found in languages with fixed word order.
\end{abstract}

Keywords: left periphery; topic; topicalization; left dislocation; relative clause; proleptic accusative

Resum. Tematitzacions, dislocacions a l'esquerra i la perifèria esquerra

La meva intenció en aquest article és proporcionar una descripció tan completa com sigui possible dels diferents tipus de tòpics en llatí. Després de definir les característiques i propietats del que anomeno Dislocacions (tòpics penjats i dislocacions a l'esquerra amb clític) i Topicalitzacions, passo a fer una descripció de cada mecanisme morfològic o sintàctic emprat en llatí: SDet preposicional, marcatge de cas, clàusules amb anteposició. A continuació proposo una hipòtesi sobre la cartografia de la perifèria esquerra en llatí. A més, presento una breu descripció d'una forma original de topicalitzar els subjectes de les oracions subordinades, és a dir, la construcció amb acusatiu prolèptic. La conclusió principal és que la cartografia de la perifèria esquerra llatina no és gaire diferent de la que es troba en llengües amb ordre fix de mots.

Paraules clau: perifèria esquerra; tòpic; topicalització; dislocació a l'esquerra; oració de relatiu; acusatiu prolèptic

* I want to thank the anonymous reviewers of this paper for their very helpful remarks. 


\section{Table of Contents}

$\begin{aligned} \text { 1. Introduction } & \text { 5. Positions of topic phrases in the left } \\ \text { 2. Topics and Topicalizations } & \text { periphery } \\ \text { 3. Dislocations } & \text { 6. Conclusion } \\ \text { 4. Topicalizations } & \text { References }\end{aligned}$

\section{Introduction}

In Latin, as in many other languages, there are various ways of emphasizing the Topic, either by means of the anticipation of a constituent (1), or by dislocation, with a resumptive pronoun (2):

(1) Hunc sui ciues e ciuitate eiecerunt (Cic. Sest. 142) Him-ACC his citizens:NOM from the city:ABL banish: $3^{\text {rd }}-\mathrm{PERF}$ 'He, his own fellow-citizens banished him from the city'

(2) Cancer ater, is olet et saniem spurcam Ulcer black:NOM it-NOM has-a-foul-odour:3rd and pus putrid:ACC mittit $^{2}$ (Cato agr. 157,3) exude: $3^{\text {rd }}$-PRST

'The black ulcer, it has a foul odour and exudes putrid pus'

These constructions systematically exhibit fronting positions of the Topics, whereas Latin is supposed to be an example of a free word order language. Given that other discourse functions, such as Focus, are expressed by fronting positions, many scholars assume that Latin is a discourse configurational language (Kiss 1995, Devine \& Stephens 2006, Danckaert 2012: 18, 21 ff.). In the Generative framework, Rizzi's 1997 paper is the starting point for a large range of studies dealing with the syntactic position of Topics in the cartography of the sentence ${ }^{3}$. Actually in many studies it is assumed that the Left Periphery does indeed exist in Latin and that Topic positions belong to this domain of the sentence, as in the case of fixed word order languages (Alvarez Huerta 2010, Bortolussi 2011, Danckaert 2012, Faure 2013).

In this paper I will assume that there are two types of topicalizations in Latin: in the first one (Dislocations) DPs are base-generated in a position of the Left Periphery; in the second (Topicalizations ${ }^{4}$, in a narrow sense) the DP has moved from an internal position to a position in the Left Periphery (in independent clauses,

1. Translations come from the Loeb Classical collection, with some modifications aimed at making the syntactic structures and pragmatic functions clearer.

2. As we will see later, this construction appears in colloquial Latin or in some technical texts in which redundancy is used to make advices clearer (Adams 2013).

3. See Belletti (2004), Rizzi (2004), Rizzi \& Bocci (forthcoming). The CP hypothesis has been extended to DPs: see for example Giusti \& Oniga (2007) on Latin.

4. I will here borrow the terminology from Corblin \& de Swart (2004), as I did previously in Bortolussi (2011). 
as well as in subordinated clauses). An interesting phenomenon, the so-called "proleptic accusative" ${ }^{5}$, could be an alternative way ${ }^{6}$ of topicalizing the subjects of some subordinate clauses:
(3) Metuo fratrem ne intus sit (Ter. Eun. 610-611) be afraid $: 1^{\text {st }}$ brother-ACC NEG-CONJ inside be: $3^{\text {rd }}-S U B J$.
'I am afraid my brother may be in there'

I first wish to come back to the definitions of Topic and Topicalization; the aim is to distinguish between (left-)dislocations with comma intonation and topicalizations without comma intonation. Then I will present various types of Dislocations and Topicalizations in Latin. In conclusion, the study will deal with three problems: the ambiguity of some Latin constructions, the question of multiple extractions, and the recursiveness of topicalization. I will try to suggest some indirect (morphological, syntactic, etc.) criteria allowing us to identify the exact status of the different fronting DP we encounter. In the last section of the paper, I will conclude my investigation by providing a cartography of the Left Periphery of Latin sentence.

\section{Topics and Topicalizations}

\subsection{Some problems in defining Topic and Topicalization}

In Functional Grammars, despite differences between authors regarding the Topic, the starting-point is a pragmatic one, namely the speaker's purposes. In her study about Latin word order, Spevak provides the following definition of the Topic:

The pragmatic function of the Topic, "what is being talked about", can be assigned to entities (persons, objects, localities, etc.). (...) According to their status in the discourse, Functional Grammar distinguishes several types of Topics: Discourse Topic, Future (New) Topic, Given Topic, Resumed Topic and Sub-Topic. (Spevak 2011: 6)

Topic constituents are syntactically characterized by their place in initial position.

In a rather different approach, Rizzi (1997), using Cinque's (1997) analyses, focuses on syntactic and prosodic features:

The topic is a preposed element characteristically set off from the rest of the clause by "comma intonation" and normally expressing old information, somehow available and salient in previous discourse. (Rizzi 1997: 285)

In addition to fronting position, syntactic dislocation and resumptive pronoun are the main features indicating topic status; this led Rizzi to identify syntactic

5. The subject of the embedded clause seems to be moved in position of object in the main clause. See part 3.4. and Bortolussi (2012).

6. See Faure and Oliviéri (2013) who compare Latin/Greek and Occitan; they propose to define the proleptic accusative as a "third way" of Topicalization. 
positions outside the VP and IP/TP layers of the sentence, namely in the sentence's (left) periphery.

Topicalization can be defined as the way of marking a constituent as a Topic. Whereas subjects are, according to functional grammars, "natural" Topics of sentences, fronting position is the way of marking any other constituent as a topic.

In Generative Grammar the functional phrases belong to the left periphery of the sentence. In Latin, as in many languages, Topic Phrases precede Focus Phrases:

(1) Hunc sui ciues e ciuitate eiecerunt (Cic. Sest. 142)

(4) a. statuam auream nec in urbe nec in ulla parte statue gold-ACC and.not in city:ABL and.not in any country:ABL Italiae $\quad$ quisquam ... aspexit (Val. Max. 2,5,1) Italy:GEN nobody:NOM see: $3^{\text {rd }}-\mathrm{PRF}$.

'A gold statue, none was seen by anyone neither at Rome nor in any Italian country'

(4) b. Sed omnium istius modi querelarum in moribus

But all:GEN that sort:GEN complaints:GEN in character:ABL est culpa, non in aetate. (Cic. Cato 7)

be-3 ${ }^{\text {rd }}$-PRST blame:NOM NEG in age:ABL

'But as regards all such complaints, the blame rests with character, not with age.'

In the last examples an Aboutness Topic precedes contrastive Foci.

The positions labelled Topic Phrases are occupied either by DP which are based-generated or by DP moved from VP and IP domains. For example we assume that hunc in (1) is moved in fronting position, because objects in the accusative case usually appear after the subject in unmarked SOV word order?

(5) Terentia magnos articulorum dolores habet

Terentia:NOM great:ACC joints:GEN pains:ACC have: $3^{\text {rd }}$-PRST

'Terentia has a severe attack of rheumatism'

Although hunc in (1) is topicalized, it is not obvious that there is a comma intonation. In example (2) the subject position is occupied by a resumptive pronoun and cancer ater does not play any function in the matrix clause, so we can consider that cancer ater has been base-generated in this fronting position.

\subsection{Semantic and syntactic types of Topics}

Different types of Topics have been identified in functional grammar literature: discourse topic, sentence topic, and, in the latter, different kinds of topics: aboutness topic, contrastive topic, scene-setting topic. ${ }^{8}$

7. See Bauer (2010: 253ff) who provides a comprehensive overview of this issue.

8. For example, Per uer haec fieri oportet (Cato agr. 40,1) "In the spring here is what to do" vs. Vergilius eam per uer seri iubet (Plin. NH, 18,120) "Virgil recommends that it should be sown in spring". 
From a syntactic point of view many studies deal with the nature and hierarchy of Topic Phrases. Unlike Rizzi (1997), who hypothesizes a recursive operation of Topicalization generating a small little set of Topic Phrases, Benincà and Poletto (2004: 52) assume "that there is a one-to-one relation between position and function, in our case between each pragmatic interpretation and a syntactic position in CP." That is to say each Topic Phrase has to be labelled on the basis of the type of element it can host. In that respect, for example, scene-setting topics and aboutness topics are not similar Topic Phrases, and the first mentioned would thus precede the second.

Regarding the form of the Topic Phrases, in many studies two main types of dislocations are distinguished, which Latin also seems to exhibit:

a) Hanging Topics, which are syntactically independent of the core sentence and which exhibit specific (morphological) marks:

(6) Les filles, elle leur a donné des exercices d'algèbre

'The girls, she gave them algebraic exercises'

(2) Cancer ater, is olet et saniem spurcam mittit. (Cato agr. 157,3)

b) Clitic Left Dislocations (usually called Left Dislocations): the Topic Phrase here hosts a DP in the form corresponding to its function in the sentence in which a resumptive pronoun may appear:

(7a) Aux filles, elle (leur) a donné des exercices d'algèbre

(7b) Edepol uel elephanto ${ }_{i}$ in India / quo pacto e $\underline{i}_{i}$ pugno by.Pollux or elephant:DAT in India:ABL how he:DAT fist:ABL praefregisti brachium! (Plaut. Mil. 25-26) smash:3 $3^{\text {rd }}-$ PERF leg:ACC

'And that elephant in India! How your fist did smash his forearm to flinders!'

The third syntactic type I call Topicalization concerns all types of XP conveying all types of topics, without any comma intonation or resumptive pronoun. Their form corresponds to that which they would have in situ:

(8) Aux filles elle a donné des exercices d'algèbre

(1) Hunc sui ciues e ciuitate eiecerunt (Cic. Sest. 142)

\subsection{Diastratic differences}

Whereas Topicalizations are used in all registers of Latin language and in all types of texts from all periods, Dislocations with resumptive pronouns belong to colloquial language. These two constructions are thus actually found competing in a small number of Latin texts: the comedies of Plautus and Terence, technical texts from all periods (Cato, mulomedicina Chironis), low-style Christian texts (itinerarium Egeriae), i.a. ${ }^{9}$

9. See Halla-aho (2016). 
Clear evidence of this diastratic difference comes from Bible translations. Whereas in Vetus Latina dislocations (with a resumptive pronoun) are found (9a), Jerome avoids using them in the Vulgata, considering them to belong to too low a level. He replaces them by topicalizations (9b) which are common in classical literature: ${ }^{10}$

Gen. 13,15:

(9) a. VL (ap. Ambr. Abr. 2,7,37; Aug. quaest. hept.,1, 28) :

\section{Omnem terram}

all land:ACC

quantum/quam tu uides, tibi dabo eam which:ACC you:NOM see: $3^{\text {rd }}$-PRST you:DAT give: $1^{\text {st }}$-FUT it:ACC

b. Vulg.: Omnem terram quam conspicis tibi dabo 'for all the land which you see, I will give to you'

\section{Dislocations}

As in many other languages, Latin often exhibits an overt grammatical marking, in particular for aboutness topics.

\subsection{Prepositional marking}

3.1.1. De + ablative case $e^{11}$

$D e+$ ablative is the most common way to introduce an aboutness topic. Evidence for dislocation is given by examples such as (10):

(10) a. de Tirone, cura, quaeso ... ut sciam about Tiro:ABL ensure:IMPR please that know: $1^{\text {st }}$-SUBJ quid is agat (Cic. Att. 10,4,4) what he:NOM do: $3^{\text {rd }}-$ SUBJ

'As for Tiro, please keep me posted up in news about his condition'

b. de Hispaniis non dubitabat quin Caesaris about Spains-ABL NEG have doubt: $3^{\text {rd }}$-IMPF that Caesar:GEN essent (Cic. Att. 10,4,8)

be: $3^{\text {rd }}$ - SUBJ-IMPF

'As for the two Spains, he had no doubt that Caesar got them'

In those examples, $d e+$ DPs are found in fronting positions of complex sentences and are dislocated from the embedded clause in which an anaphoric pronoun (is in (10a) and a null subject in (10b)) sums up the DP. Moreover, we can assume

10. See Bortolussi and Sznajder (2014).

11. See Rosén (1992), Molinelli (1999). 
that these PPs cannot remain in the periphery of the embedded clause and that they move to the left periphery of the matrix clause.

In many constructions the status of $d e+$ abl. is less clear: it could be considered either as a dislocated PP (Hanging Topic) or as a PP moved into a fronting position (Topicalization). See for example (11):

(11) De Buthroti negotio, utinam quidem Antonium About Buthrotum:GEN business:ABL may at least Anthony:ACC conueniam!

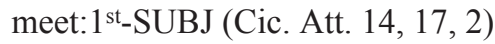

'As regards the business about Buthrotum I only wish I could meet Anthony!'

This sentence can be derived from:

(11') Vtinam Antonium de Buthroti negotio conueniam!

In this case the aim of the encounter with Antonius is to discuss specifically the business of the Buthrotum; if de Buthroti negotio is dislocated, the sentence means that one way of solving the Buthrotum problem is an encounter with Antony.

\subsubsection{Quantum ad + accusative case}

As the ancestor of the French quant à and Italian quanto a, quantum ad is used to introduce a new topic or a contrastive topic. It appeared after the classical period and its origin derives from an elliptic construction: quantum ad aliquem pertinet/ adtinet 'as far as someone is concerned':

(12) a. Quantum ad porticus, nihil interim occurrit (Plin. epis.

as for colonnade:ACC nothing in the interval occurred: $3^{\text {rd }}$-PERF 'As for the colonnade, nothing occurred to me in the interval.'

b. Quantum ad me pertinet, laborabo ut... (Plin. as far for me:ACC concern-3 $3^{\text {rd }}$-PRST work: $1^{\text {st }}-$ FUT to Sec. pan. 3,2) 'As far I am concerned/as for me, I will try to...'

It seems that the development of this construction - beginning with Seneca, who introduced abstract nouns indicating philosophical scene-setting topics and the replacement of $d e+$ abl. in medieval literature stems from scholastic influence.

\subsection{3. ab + ablative case Topicalization marks}

More rarely, the preposition $a b$ ( + ablative case) is used in the same way as quantum ad + abstract noun: 

A morbo
ualui,
ab animo
aeger fui. (Plaut. Epid.

from disease:ABL be well: $1^{\text {st }}$ PRF from heart:ABL sick be:1 ${ }^{\text {st }}$-PRF

'Regarding physical diseases, I was well, but regarding my heart I was sick'

$A b$ does not convey here its usual meaning, "far from/starting from".

\subsection{Case marking}

\subsubsection{Nominativus pendens}

Nominativus pendens is the most popular Latin type of dislocation among linguists, constituting the typical form of Hanging Topic. We can find instances in different texts of all periods. It is in fact quite common in archaic comedies and in technical literature.

The main question is: why do we find the nominative case? At first glance, nominative is the only case (except vocative) which is not assigned inside the VP domain. So I will assume that the nominative is the only case that can be assigned to the specifier of a functional category (AgrP or TopP).

This specific casual form is associated with the presence of a resumptive pronoun:

(14) ceterae philosophorum disciplinae ..., eas ...

all other:NOM philosophers:GEN systems:NOM them:ACC

nihil adiuuare arbitror (Cic. fin. 3,11)

nothing:ACC help:INF believe:1 $1^{\text {st }}$ PRST

'All other philosophical systems do not merely, as I hold, give us no assistance'

Nominativus pendens can be used with null resumptive pronoun in the clause:

(15) Nam nos omnes quibus est aliquis obiectus for us all:ACC who:DAT be $: 3^{\text {rd }}$-PRST some set-against labor/ omne interea tempus priusquam id rescitum trouble:NOM all meanwhile time:NOM before it:NOM known est, lucrost (Ter. Hec. 286) be: $3^{\text {rd }}$ gain:DAT-be: $3^{\text {rd }}-$ PRST

'For all of us know who have met with trouble from any cause, that all the time that passes before we come to the knowledge of it, is so much gain.'

\subsubsection{Accusativus pendens}

In very rare examples, the accusative case is employed instead of nominative:

(16) Puteolos ..., Pompeios, hae sunt uerae Pozzuoli:ACC Pompei:ACC those:NOM be $3^{\text {rd }}$-PRST real coloniae (CIL IV, 3525)

colonies:NOM

'Pozzuoli, Pompei, those are real colonies' 
In this construction the accusative can be considered as a default case (see Calboli 1996) competing with the nominative.

\subsubsection{Clitic Left Dislocations?}

Apparently Clitic Left Dislocations do exist in Latin:
a. Amicos $s_{i}$ domini, habeat sibi friends:ACC master:GEN them:ACC consider: $3^{\text {rd }}$-SUBJ he:DAT amicos (Cato agr. 5, 3)
friends:ACC
'The master's friends, he must consider them his own friends'
b. Nostro seni huic stolido, $\underline{e i}_{i}$ profecto nomen our old-man this stupid:DAT he:DAT certainly name:ACC facio ego Ilio. (Plaut. Bacch. 945)

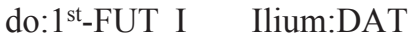 'This silly old man of ours, I dub him Ilium'

In those examples the fronting dislocated DPs exhibit the same case as the resumptive pronoun. An important difference remains: in Latin most examples present a strong pronoun instead of a clitic one. ${ }^{12}$ Actually the resumptive pronoun is focalized, as example (17a) shows, with an implicit contrastive focalization. Examples with resumptive pronouns in weak positions are more scarce; we find some examples in Biblical texts where they are calques of their Greek sources (and as indirect calques from Hebrew constructions ${ }^{13}$ ):
(18) timentis $_{\mathrm{i}}$
Dominum beata est
anima
eius $_{\mathrm{i}}($ Sir. 34,17)
fearing:GEN Lord:ACC blessed be:3 ${ }^{\text {rd }}$-PRT soul:NOM of-him:GEN
'The man who fears the Lord, his soul is favored'

This shows that, even if weak pronouns are not exactly clitic, they are in the way of cliticization by being postponed to their syntactic head.

Whatever the procedure adopted for analyzing these constructions, some other examples could be analyzed as CILD, if we admit that they contain a null anaphoric pronoun, in particular in the case of partial extraction from a postponed embedded clause: ${ }^{14}$

12. I follow Salvi (2004) who distinguishes "strong" and "weak" pronouns in Latin, although there is no morphological evidence. The difference leans on syntactic distribution: "weak" pronouns cannot appear in fronting or stressed positions.

13. On topicalizations and left dislocations in Biblical Latin see Bortolussi \& Sznajder (2014). Note that Jerome did not translate Sirach; so this example does not reflect his strategy, but a rather lower style. A long-distance anaphoric relation is illustrated by: uenit fortior me post me cuius non sum dignus procumbens soluere corrigiam calciamentorum eius (NT. Marc. 1,7) ”Е $\rho \chi \varepsilon \tau 1$ ó

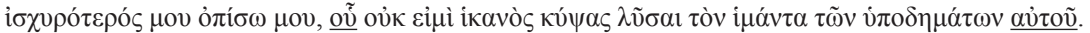

14. According to Danckaert (2012) partial extractions are easier from complement clauses than from adverbial clauses. 
(19) Stoicorum autem non ignoras [quam sit subtile, uel Stoics:GEN NEG ignore $: 2^{\text {nd }}-P R T$ how be $: 3^{\text {rd }}-S U B J$ subtle or spinosum potius pro $_{i}$ disserendi genus] (Cic. fin. 3,3) crabbed more rhetoric style:NOM 'But the Stoics, as you are aware, how exceedingly subtle or crabbed is the style of arguments they affect'

\subsection{Dislocated clauses}

\subsubsection{Quod-clauses}

Quod-clauses in fronting position play the role of aboutness topics:

(20) Nam quod se similem esse Catilinae gloriari for that he:ACC like be:INF Catiline:GEN boast:INF solet, scelere par est illi, use-to: $3^{\text {rd }}$ PRST wickedness:ABL equal be: $3^{\text {rd }}$-PRST to-him:DAT industria inferior (Cic. Phil. 4,5) energy:ABL inferior 'For, as for his usual boast that he is like Catiline, he is equal to him in wickedness, but inferior in energy'

This is a kind of relative clause without antecedent. As a matter of fact, in some cases $Q u o d$-clauses are resumed by anaphoric pronouns:

(21) [Quod autem magnum dolorem breuem, longinquum leuem esse that great pain:ACC short prolonged light be:INF dicitis], id non intellego quale sit. (Cic. fin. 2, 94) say:2 ${ }^{\text {nd_PRST }}$ it:ACC NEG understand:1 ${ }^{\text {st_PRST }}$ what be: $3^{\text {rd }}-$ PRST 'As for your maxim that severe pain is short and prolonged pain light, I cannot make out what it may mean.'

\subsubsection{Relative clauses}

The ancient correlative structure qui..., is... became a strategy of topicalization in Latin. The fronting relative clause competes in most examples with a Hanging Topic DP. Four types of fronting relative clauses can be found: ${ }^{15}$

1) autonomous (or free) relative clauses referring to generic DPs:

(22) [Cuius autem aures clausae ueritati sunt]..., huius whose:GEN ears:NOM closed truth:DAT be:3 $3^{\text {rd }}-P R T$ he:GEN salus desperanda est (Cic. Lael. 90) safety:NOM despair:PASS-OBLIG be:3rd-PRT 'The man whose ears are so closed to truth, we must now despair of his safety' 
2) relative clauses containing their nominal head (circumnominal relative clauses in Lehmann 1984: 48):

(23) [Quam quisque norit artem], in hac se which:ACC each:NOM know: $3^{\text {rd }}$ PRF art:ACC in this:ABL himself exerceat. (Cic. Tusc. 1,41) employ: $3^{\text {rd }}-$ SUB

'The art which each man knows, in this let him employ himself'

This type of relative clause looks like a definite DP, its head is the N included in it.

3) relative clauses with inverse attraction:

a. Mulier [quae se $\quad$ suamque aetatem spernit],
woman:NOM who:NOM herself:ACC her-and age:ACC neglect:3rd-PRT
speculo ei $\quad$ usus $\quad$ est. (Plaut. Most. 250)
mirror:DAT to-her:DAT utility:NOM be:3 $3^{\text {rd-PRST }}$

'A woman who neglects herself and her youthful age, she needs a mirror'
b. hunc chlamydatum [quem uides], ei Mars this guy-with-cloak:ACC whom see:2 ${ }^{\text {nd }}-P R T$ he:DAT Mars:NOM iratust (Plaut. Poen. 644)
angry-be: $3^{\text {rd }}$-PRT
'his guy you see in the military cloak - he's under the curse of Mars'

In the first example mulier could be considered as having been moved from the internal position to the left periphery of the clause. The difficulty is then to explain how the case is copied through COMP, usually considered as a barrier. ${ }^{16}$ The second example is more difficult: hunc chlamydatum cannot be extracted from the relative clause because the DP would contain two specifiers, quem and hunc chlamydatum. Indeed the DP refers to a definite person introduced as a new topic, as the demonstrative hunc indicates.

Regardless of the procedure adopted in order to explain case copy, ${ }^{17}$ the fronting DP cannot be dissociated from the relative clause it precedes, together with which it forms a Hanging Topic, with or without a resumptive pronoun in the main clause. ${ }^{18}$

16. See Bianchi (2000: 68), who analyzes this construction as a left-dislocation and puts forward some evidence in favour of case copy.

17. Alvarez Huerta (2005: 183), observing that attractio inversa concerns most of time nominative and accusative, assumes that we do not need a copy rule.

18. See for example: Naucratem $_{\mathrm{i}}$ [quem conuenire uolui], pro $_{\mathrm{i}}$ in naui non erat. (Plaut. Amph. 1009) "Naucrates, whom I wanted to find, was not on board". As in (24b) Naucratem is a definite DP. 


\section{Topicalizations}

\subsection{The relative connection (relatif de liaison) as a prototype of Topicalization}

(Danckaert 2012: $183 \mathrm{ff}$ )

Anaphoric pronouns are used to mark textual continuity and can therefore play the role of topic. In the following examples quod and eum, placed in fronting positions, act as topics of the whole sentences:
a. quod cum Sisyphus fecisset, duo sunt this:ACC when Sisyphus:NOM do: $3^{\text {rd }}-P P R F-S U B J$ two be: $3^{\text {rd }}$ filii nati (Hyg. fab. 60,2) sons:NOM born
'When Sisyphus had done this, two sons were born'
b. Eum cum uidero, Arpinum pergam(Cic. Att. 9,15,1) him:ACC when see:1st-FUTPRF Arpinum:ACC move-to: $1^{\text {st-FUT }}$ 'When I have seen him, I'll move on to Arpinum' (Danckaert 2012: 2)

Let us take the relatif de liaison as the prototypical way of topicalization. This wh-phrase automatically refers to an already established discourse referent. The properties it reveals are the following:

a) Like other QU-words, it must be moved, whatever its function, from its in situ position to a position in $\mathrm{CP}$.

b) It can be moved from an embedded clause:

(26) Quod [quam magnum sit] fictae ueterum this:ACC how great:ACC be:3rd-PRT invented old-time:GEN fabulae declarant (Cic. fin. 1,65)

fictions:NOM show: $3^{\text {rd }}$

'How it is important, the legends from the ancient time show it'

c) It precedes all other phrases belonging to the Left Periphery, including subordinators and all QU-words:

(27) Quo quid absurdius dici aut existimari potest? that:ABL what more-absurd be-said:INF or be-thought:INF can:3 $3^{\text {rd }}$ (Cic. Phil. 8,4)

'And what can be said or thought of more absurd than that?'

d) It is not resumed by another (anaphoric) pronoun. ${ }^{19}$

Every XP exhibiting those properties can be considered as occupying a Topic Phrase position. The main difficulty concerns the ambiguity of many constructions:

19. We can therefore mention Plaut. Trin. 1023 quorum eorum unus surrupuit currenti cursori solum. There is no need to consider that there are two independent pronouns (for a discussion see Touratier 1980: 482-514), the first in a Topic position, the second in situ. All other examples are from Biblical Latin. See supra note 6. 
— Hanging Topic or Topicalization?

(28) qui inuident egent; illis quibus inuidetur, who:NOM be-envious: $3^{\text {rd }}$ are-missing: $3^{\text {rd }}$ these who:DAT be-envious: $3^{\text {rd }}$ i rem habent (Plaut. Truc. 745)

they thing:ACC have: $3^{\text {rd }}$

'Those who are envious, are in want; they who are envied, possess property'

Here the symmetry between the two contrastive sentences leads us to assume that the first one has to be analysed in the following way:

(28')qui inuident, pro egent

- CILD or Topicalization?

(29) Commentarios quosdam, inquam, Aristotelios, [...], ueni ut commentaries:ACC some say: $1^{\text {st }}$ Aristotelian:ACC come: $1^{\text {st-PFT }}$ for auferrem (Cic. Fin. 3.3.10) ${ }^{20}$

pick-up: $1^{\text {st_-SUBJ }}$

'I came to take away some commentaries on Aristotle'

When a fronting DP is the topic of an embedded clause, it is hardly plausible to analyze it as a Topicalization, because it would imply a long distance extraction from an adverbial clause:

(30) $[\text { Commentarios quosdam Aristotelios }]_{\mathrm{i}}[\ldots]$ ueni $\left[\right.$ ut $t_{i}$ auferrem $]$

The alternative solution is to analyze the construction as a CILD with a null resumptive pronoun:

(31) $[\text { Commentarios quosdam Aristotelios }]_{\mathrm{i}}[\ldots]$ ueni $\left[\right.$ ut pro $_{i}$ auferrem]

In order to clear up these ambiguities we can draw on some indirect evidence.

\subsection{Indirect evidence of topicalization}

a) Topicalizing connectors

The main function of autem and uero is to introduce the DP they follow as a topic (Kroon 1995):

20. Because of the scarcity of such examples, Danckaert (2012) assumes that "extraction out of adjuncts is to be considered a stylistic phenomenon." 
(32)
a. te uero,
C. Claudi,
adhortor
ut... (Liu. 3,21,17)
you:ACC
C. Claudius:VOC
urge: $1^{\text {st }}-$ PRST that
'as for you, C. Claudius, I urge that...'

b. uobis autem, Ardeates, fortuna oblata est you:DAT men-of-Ardea:VOC opportunity:NOM provided be: $3^{\text {rd }}$-PRF (Liu. 5,44,3)

'But you, men of Ardea, have now an opportunity'

b) Personal pronouns

Adams (1994) and Védrenne (2013) assume that weak pronouns, in Wackernagel's position, play the role of Topic shifters:

(33) Hanc ego Lucinae credo fuisse manum. this:ACC I Lucina:GEN think: $1^{\text {st }}$ be:INF-PAST hand:ACC (Mart. Lib. Spect. 15,3)

'This hand, I think it was Lucina's one'

c) Fränkel's Kolon-theory

According to Fränkel (1964), the sentence is not the only domain concerned by Wackernagel's law; his Kola can be identified in prose by the location in Wackernagel's position of particles and weak pronouns. In the following example the Topic Phrase is marked, as we have already seen, by autem. A confirmation is given by the Wackernagel law position of me, indicating that the last part of the sentence forms the second Kolon:

(34) De triumpho autem / nulla me cupiditas umquam tenuit ...

(Cic. Att. 7,2,6)

about triumph:ABL no me:ACC desire:NOM never keep:3rd-PRF Kolon 1 / Kolon 2

'As for the triumph, I absolutely never desired it'

4.3. Contrastive topics (Devine and Stephens 2006: 43-44)

Evidence of topicalization can come from fronting DPs in contrastive sentences:

(35) bouem eximium Marti immolauit, centum boues ox:ACC outstanding Mars:DAT sacrify: $3^{\text {rd }}$ PRF hundred oxes:ACC militibus dono dedit (Liu. 7,37,3)

soldiers:DAT gift:ABL gave: $3^{\text {rd }}$

'The choice ox he sacrificed to Mars, the hundred oxen he gave as a gift to the soldiers' (Devine \& Stephens 2006: 44)

The topic function can be highlighted by uero (see (28)): 
(36) Mihi uero erit gratum ...-Ego uero non grauarer, si I:DAT be: $3^{\text {rd }}-F U T$ agreable I:NOM NEG be-saddened: $1^{\text {st }}$ if mihi ipse confiderem. (Cic. Lael. 16-17) I:DAT myself be-confident: $1^{\text {st }}$ 'Indeed it will be agreable to me... - I certainly should raise no objection, if I felt confidence in myself.'

\section{Positions of topic phrases in the left periphery}

I will begin from the foregoing analyses in order to make some proposals regarding the positions of topic phrases; then I will deal with two additional issues regarding embedded clauses: multiple extractions and the proleptic accusative.

\subsection{Position of Topic Phrases in simple sentences}

a) after Force:

(37) Vt illum di deaeque perdant!(Ter. Eun. 302)

may he:ACC gods goddesses:NOM-and confound: $3^{\text {rd }}-$ SUBJ

'May all the Gods and Goddesses confound that old fellow'

I assume, following Rizzi (1997), ${ }^{21}$ that illocutionary adverbs and conjunctions, for example $u t$ and utinam, are in Force position. Two analyses of (37) are possible: (i) scrambling of illum from its position to the left of IP, ${ }^{22}$ due to its pragmatic function; Force and Finiteness are supposed to be expressed on a single head; (ii) movement from IP to a position between Force and Finiteness, if we suppose an empty Finiteness phrase.

b) between Force and Focus

Force and Finiteness are split when the Topic-Focus field is activated (Rizzi 1997: 314) and Topic phrases are inserted between them:

(38) Quid ? Theophrastus

Force Top.

What Theophrastus:NOM moderately-INTER be-glad: $3^{\text {rd }}$

The adverb quid reflects the interrogative force of the whole sentence and mediocriter joined to the interrogative particle -ne is focalized.

21. "Complementizers express the fact that a sentence is a question, a declarative, an exclamative, a relative, a comparative, an adverbial of a certain kind, etc., can be selected as such by a higher selector. This information is called the specification of Force..." (Rizzi 1997: 283).

22. See Devine \& Stephens' analysis (2006: 99) of Qui ciuitatem regio dominatu liberauit (Cic. Planc. 60) "who set the state free from regal despotism". They assume that scrambled DPs convey weak pragmatic functions. 
c) before Force

We are facing a great difficulty in examples like:

(39) Eas ipsas (umbra et imagines iustitiae) utinam sequeremur! (Cic. Off. 3,69) these themselves:ACC

'I only wish that we were true even to this'

The topic is moved in a fronting position at the left of the adverb expressing wishes. Two analyses of this type of structure have been proposed: (i) the assumption that there is a null Force phrase and that the adverb is set in Finiteness; ${ }^{23}$ (ii) the assumption that Topic can move to the left of Force (Bianchi 2000: 72).

Constructions like (39) are much more frequent than (37). This therefore constitutes an argument in favour of the latter solution.

\subsection{Position(s) of Topic Phrases in complex sentences}

a) Left Edge Fronting (Danckaert 2012). In adverbial clause Topic phrases can precede the conjunction:

(25b) Eum cum uidero, Arpinum pergam (Cic. Att. 9,15,1)

L. Danckaert (2012: $143 \mathrm{ff}$ ) assumes that the entire adverbial clause is piedpiped by the fronting DP in the fronting position of the sentence.

b) Position in the left periphery of the matrix clause. The topic of a complement clause can be moved to the left periphery of the matrix clause. It is often the subject (40), but all DPs, whatever their function in the embedded clause, can be moved (19):

(40) Orator metuo [ne languescat senectute].

orator:NOM fear: $1^{\text {st }}$ that-NEG be-weakened: $3^{\text {rd }}$-SUB old-age:ABL

'The orator, I fear, does lose in efficiency on account of old age'

$\left[_{\mathrm{CP} 1}\right.$ Orator $_{\mathbf{i}}\left[_{\mathrm{IP} 1}\right.$ metuo $\left[{ }_{\mathrm{CP} 2}\right.$ ne $\left[_{\mathrm{IP} 2}\right.$ t/pro $_{i}$ languescat senectute $\left.\left.]\right]\right]$

(19) Stoïcorum autem non ignoras [quam sit subtile, uel spinosum potius disserendi genus]. (Cic. fin. 3,3) ${ }^{24}$

23. See Danckaert (2012) about DPs on the left side of adverbial embedded clauses.

24. More frequent is the pied-piping of the whole DP. 


\subsection{Multiple "extractions"}

5.3.1. Multiple "extractions" from embedded clauses (Danckaert 2012)

It has been observed by Amacker (1998) in Cato's corpus that most phrases can be extracted from a complement clause without any reason other than as a stylistic device. In some cases the verb is the only word remaining inside the embedded clause:

(41) a. atque quanto, Nox, fuisti longior hac proxuma, / tanto and so much night:VOC be:2 ${ }^{\text {nd }}$ PFT longer this last:ABL so much breuior dies [ut fiat] faciam (Plaut. Amph. 548-549) shorter day:NOM to become: $3^{\text {rd }}-$ SUB make: $1^{\text {st-FUT }}$

'And, Night, since you were longer than the last, I will make the day so much the shorter'

b. Tune id dicere audes, quod nemo you:NOM-INTER this:ACC tell:INF dare: $2^{\text {nd }}$ which:ACC no one:NOM umquam homo antehac/uidit nec potest ever man:NOM before see: $3^{\text {rd }}-P R S T$ and.not can: $3^{\text {rd }}$ fieri, tempore uno / homo idem duobus locis be:INF time:ABL man:NOM same two places:ABL [ut simul sit]? (Plaut. Amph. 566) that same-time be: $3^{\text {rd }}-$ SUB "You dare tell me a thing no one ever saw before, an impossible thing - the same man in two places at one time?"

L. Danckaert (2012: $241 \mathrm{ff}$.) assumes that in multiple Left Edge Fronting only the first DP has to be considered as the Topic, whereas the others convey other pragmatic functions or are scrambled phrases:

(42) [Quibus ille [si cedit], salui sumus]]. (Cic. Att. 5,20,8) those:DAT he:NOM if give-in: $3^{\text {rd }}$ safe be: $1^{\text {st }}$-pl

'If he gives in to those, then we are safe.'

In this example the relatif de liaison is the topic, whereas ille may be considered as focused.

\subsubsection{Hierarchy of topic phrases}

Many studies, starting from Rizzi (1997), reject the hypothesis that Top. positions are recursive and assume that each pragmatic subtype of topic is located in a specific position, according to its discourse properties. ${ }^{25}$

Insofar as we lack a complete paradigm of the different types of topics, we can hardly establish a reliable and fine cartography of the left periphery. However, the 
few examples we have come up with suggest the combinations discursive topicinanimate aboutness topic:

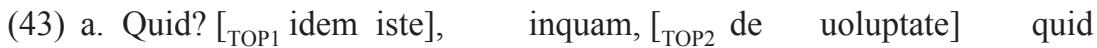
what same that:NOM say: ${ }^{\text {st }}$ about pleasure:ABL what sentit? (Cic. Fin. 2,8)

think: $3^{\text {rd }}$

'Well, said I, what is the same philosopher's view about pleasure?'

b. $\left[_{\text {TOP1 }}\right.$ Tu autem], Fanni, $\left[_{\text {TOP2 }}\right.$ quod mihi tantum tribui you:NOM Fannius:VOC that I:DAT so-great ascribe:INF-PAS dicis, quantum ego nec agnosco nec postulo], facis say:2 $2^{\text {nd }}$ such as I:NOM and.not admit: $1^{\text {st }}$ and.not claim: $1^{\text {st }}$ do: $2^{\text {nd }}$ amice. (Cic. Lael. 9)

kindly

'Now as for your saying, Fannius, that so great merit is ascribed to me merit such as I neither admit nor claim - you are very kind.'

In this last example, both phrases seem to be Hanging Topics.

5.4. Proleptic accusative (Bortolussi 2012, Álvarez Huerta 2007, Halla-aho 2012)

Proleptic accusative constructions compete with other "extractions" from complement clauses. Like LEF-constituents, proleptic accusative DPs often precede the conjunctions, both in postponed embedded clauses and also in preceding embedded clauses:

(44) a. nunc demum scio ego [hunc [qui 1 sit]] now at last know: $1^{\text {st }}$ I:NOM him:ACC who:NOM be: $3^{\text {rd }}-S U B$ (Plaut. Epid. 458)

'Now at last I know who he is'

b. simul [hanc rem [ut facta est]] eloquar at-the-same-time this thing:ACC how done-be: $3^{\text {rd }}$ say: $1^{\text {st-FUT }}$ (Plaut. Amph. 1129)

'at the same time I'll tell him all that is happened'

However they can be dislocated from the embedded clause and occupy a fronting position in the matrix clause:

(45) Chlamydem hanc commemora [quanti conductast] (Plaut. Pseud. 1184) cloak:ACC this tell:IMPR how much hired-be: $3^{\text {rd }}-\mathrm{PFT}$

'This cloak - come, tell us how much it cost to hire'

However there are some differences: the phenomenon is restricted to a small set of complement clauses and the proleptic DP can be resumed by an anaphoric 
pronoun. Those observations lead us to analyze proleptic accusative differently from LEF. I assume that

- proleptic accusatives are base-generated in Hanging Topic position in the left periphery of the embedded clause;

- in that position, the accusative case may be assigned by the verb of the matrix clause;

- the DP can be moved from its initial position to a position in the left periphery of the matrix clause; the proleptic DP rises to the higher position by a recursive movement:

(46) a. Est quidam homo ${ }_{i}$, qui $_{i}$ illam ait $\left[t_{i}[\mathrm{se}\right.$ be: $3^{\text {rd }}$ some man:NOM who her:ACC say: $3^{\text {rd }}$ it:ACC scire $\quad\left[\right.$ pro $_{i}\left[\right.$ ubi $\left[\right.$ pro $_{i}$ sit $\left.\left.\left.\left.]\right]\right]\right]\right]$ (Plaut. Cist. 735) know:INF where be: $3^{\text {rd }}$-SUB 'There is a certain man who says he knows where it (the casket) is'

b. Nam [sanguinem, bilem, pituitam, ossa $]_{\mathrm{i}}, \ldots$ uideor for blood:ACC bile:ACC phlegm:ACC bones:ACC seem: $1^{\text {st }}$ [posse dicere $t_{i}$ [unde pro $_{i}$ concreta et quo modo facta sint]] can:INF say:INF from what compounded and how done-be: $3^{\text {rd }}$-pl (Cic. Tusc.1,56)

'As for the blood, bile, phlegm, bones, it seems to me that I can tell from what they have been compounded and how they were fashioned'

- in the left periphery of the matrix clause it can obviously occupy a Topic position, but in rare cases it can be focalized ${ }^{26}$ :

(47) Num meam saeuitiam ueritu's ? - Non-Non? quid igitur? INTER my severity:ACC fear:2 $2^{\text {nd }}$ no no what then Hanc metui [ne me criminaretur tibi].

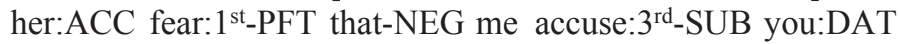
(Ter. Eun. 853-855)

'Were you in fear of my severity? - No! - No? What then? - I was afraid of her, lest she might be accusing me to you.'

\section{Conclusion}

In order to be complete, this overview would need to contain the description of scene-setting topics, in particular of adverbs and adverbial clauses in fronting position:

26. See Álvarez Huerta (2007), who assumes that proleptic accusative is focalized. 
(48)

a. Anco regnante, Lucumo... Romam

Ancus:ABL reign:PTCP-ABL Lucumo:NOM Rome:ACC commigrauit (Liu. 1,34,1)

migrate: $3^{\text {rd }}$-PFT

'In the reign of Ancus one Lucumo took up his residence in Rome'

b. Afranius cum ab equitatu nouissimum agmen

Afranius:NOM when by cavalry:ABL rearguard:NOM

premeretur et ante se hostem uideret collem

be-harassed: $3^{\text {rd }}$ and before he:ACC enemy:ACC see:3rd-SUB hill:ACC

quendam nactus ibi constitit (Caes. ciu. 1,70,3)

some reaching here halt: $3^{\text {rd }}$-PFT

'Afranius, seeing his rear continually harassed by the cavalry and the enemy in his front, went to an eminence and halted on it.'

The participial clause (ablative absolute) in (48a) and the cum-clause in (48b) set up the background of the main event. The topic Afranius, being the subject of both the adverbial clause and the main clause, is located in fronting position in the left periphery of the adverbial clause. We lack other combinations of topics that would allow us to propose a more precisely drawn-up cartography of left periphery, including set-setting topics.

The main result of this paper is the confirmation that the $\mathrm{CP}$ layer does exist in Latin and that the language exhibits what, in broad terms, are the same characteristics as in languages with fixed word order.

Our investigation shows that in Latin overt dislocations remains limited to colloquial language, whereas in most cases CILD cannot be distinguished from Topicalizations. The high frequency of these constructions, in which DPs basically seem to have been moved from any position to the left periphery, is problematic in the generative framework, insofar as some examples would illustrate island violations. A striking example is given by the movement of relative pronouns from embedded clauses to the left periphery of the main clause: ${ }^{27}$

(49) Coloneus ille locus .., quem qu $_{\mathbf{i}}$ scis quam $\boldsymbol{t}_{\boldsymbol{i}}$ Colonus this place:NOM which:ACC know: $2^{\text {nd }}-$ PRST how much admirer (Cic. fin. 5,3) admir: $1^{\text {st }}-$ SUBJ-PRST

'This village of Colonus who is as you know my great admiration'

27. This is an example of the so-called relative Verschränkung; see Bortolussi (2005) and Danckaert (2012). 


\section{References}

Adams, J. N. 1994. Wackernagel's law and the position of unstressed personal pronouns in classical Latin. The Transactions of the Philological Society 92 (2): 103-178. $<$ https://doi.org/10.1111/j.1467-968X.1994.tb00430.x>

Adams, J. N. 2013. Social variation and the Latin language. Cambridge: Cambridge University Press. $<$ https://doi.org/10.1017/CBO9780511843433>

Álvarez Huerta, O. 2005. Attraction régressive et corrélation en latin. In de Carvalho P. \& Lambert F. (eds.). Structures parallèles et corrélatives en grec et en latin (Actes du Colloque de Bordeaux, Septembre 2002), 181-197. Publications de l'Université de Saint- Étienne.

Álvarez Huerta, O. 2007. El acusativo proléptico en latín. In Purnelle G. \& Denooz J. (eds.). Cohérence textuelle et ordre des syntagmes. Communications présentées au 13e Colloque international de Linguistique latine (Bruxelles-Liège, 4-9 avril 2005), 19-29. Bibliothèque de la Faculté de Philosophie et Lettres de l'Université de Liège (diffusion Droz, Genève).

Álvarez Huerta, O. 2010. Les constructions Hanging Topic Left Dislocation et Clitic Left Dislocation en latin. Talk delivered at Colloque International de Syntaxe Grecque et Latine, Nov. $26^{\text {th }}-27^{\text {th }}$, Paris.

Amacker, R. 1998. Ordre des mots et subordination: la traiectio chez Varron. In García- Hernández, B. (ed.). Estudios de Linguïstica Latina. Actas del IX Coloquio Internacional de Linguïstica Latina, 139-154. Madrid: Ediciones Clásicas.

Bauer B., 2010, Word order. In Baldi P. and Cuzzolin P. (eds). New Perspectives on Historical Latin Syntax. Vol. 1. Syntax of the Sentence, 241-316. Berlin. Mouton de Gruyter. $<$ https://doi.org/10.1515/9783110205626>

Belletti, A., (ed.), 2004. Structures and Beyond. The Cartography of Syntactic Structures, vol. 3. New York: Oxford University Press.

Benincà, P. \& Poletto, C. 2004. Topic, Focus and V2: defining the CP sublayers. In Rizzi L. (ed.). The structure of CP and IP, The cartography of syntactic structures 2, 52-75. Oxford: Oxford University Press.

Bianchi, V. 2000. The syntax of relative determiners. In Alexiadou, A., Law, P., Meinunger, A. and Wilder, C. (eds), The Syntax of Relative Clauses, 53-75. Amsterdam: John Benjamins. $<$ https://doi.org/10.1075/la.32>

Bortolussi, B. 1998. Facite uentum ut gaudeam. Quelques phénomènes d'ambigüité syntaxique. In García-Hernández B. (ed.). Estudios de lingüistica latina. Actas del IX Coloquio Internacional de Linguïstica Latina, 203-216. Madrid: Ediciones Clásicas.

Bortolussi, B. 2005. Subordination seconde du relatif. In Calboli G. (ed.). Papers on Grammar IX 1, 479-492. Rome: Herder.

Bortolussi, B. 2011. Ordre des mots et syntaxe du latin - Les contraintes de placement et leur analyse syntaxique. Mémoire d'Habilitation à Diriger des Recherches, Paris Nanterre.

Bortolussi, B. 2012. Quelle position syntaxique l'accusatif proleptique occupe-t-il ?, Revue de linguistique latine du Centre Alfred Ernout, 7, Etudes sur la prolepse: $<$ http://www.paris-sorbonne.fr/numero-7-avril-2012>. 
Bortolussi, B. \& Sznajder, L. 2014. Topicalization versus Left-Dislocation in Biblical Latin. Journal of Latin Linguistics 13(2): 163-195. $<$ https://doi.org/10.1515/joll-2014-0007>

Calboli, G. 1996. The accusative as a default Case in Latin. In Rosén H. (ed.). Aspects of Latin: Papers From the Seventh International Colloquium On Latin Linguistics, 423-436. Innsbruck: Institut für Sprachwissenchaft.

Cinque G. 1997. 'Topic' constructions in some European languages and Connectedness. In Anagnostopoulou E., van Riemsdijk H. \& Zwarts F. (eds.). Materials on Left Dislocation, 93-118. Amsterdam: John Benjamins. $<$ https://doi.org/10.1075/la.14>

Corblin, F. \& de Swart, H. 2004. Handbook of French semantics. Chicago: CSLI Publications.

Dankaert, L. 2012. Latin Embedded Clauses. The Left Periphery (Linguistik Aktuell/ Linguistics Today 184). Amsterdam/Philadelphia: John Benjamins. $<$ https://doi.org/10.1075/la.184>

Devine, A. M. \& Stephens L. D. 2006. Latin word order. Structured meaning and information. Oxford: Oxford University Press. $<$ https://doi.org/10.1093/acprof:oso/9780195181685.001.0001>

Faure, R. \& Oliviéri, M. 2013. Stratégies de topicalisation en occitan. Dialectologie: corpus, atlas, analyses. Corpus 12: 231-270. <http://corpus.revues.org/2391>

Fraenkel, E. 1964. Kleine Beiträge zur klassischen Philologie, Bd. 1: Zur Sprache: 73-130. Roma: Edizioni Di Storia e Letteratura.

Frascarelli, M. 2007. Subjects, Topics and the interpretation of referential pro. An interface approach to the linking of (null) pronouns. Natural Language and Linguistic Theory 25: 691-734. $<$ https://doi.org/10.1007/s11049-007-9025-x>

Giusti, G. \& Oniga R. 2007. "Core and Periphery in the Latin Noun Phrase". In Purnelle, G. and Denooz J. (eds). Ordre et cohérence en Latin. Communications présentées au $13^{\circ}$ Colloque International de Linguistique Latine, Bruxelles-Liége, 4-9 avril 2005, 81-95. Genève: Droz.

Kiss, K. É. (ed.) 1995. Discourse configurational languages (Oxford Studies in Comparative Syntax). New York \& Oxford: Oxford University Press.

Kroon, C. 1995. Discourse particles in Latin; a study of nam, enim, autem, vero and at. Amsterdam: Gieben.

Haegeman, L. 2006. Argument fronting in English, Romance CLLD and the left periphery. In Zanuttini R., Campos H., Herburger E.\& Portner P. (eds). Cross-linguistic research in syntax and semantics: negation, tense and clausal architecture, 27-52. Washington (DC): Georgetown University Press.

Halla-aho, H. 2012. A historical perspective on Latin proleptic accusatives. Revue de linguistique latine du Centre Alfred Ernout, 7, Etudes sur la prolepse: $<$ http://www. paris-sorbonne.fr/numero-7-avril-2012>.

Halla-aho, H. 2016. Left-detached constructions from early to late Latin (nominatiuus pendens and attractio inuersa). In Adams J. N. \& Vincent N. (eds.). Early and Late Latin: Continuity or Change?, 367-389. Cambridge: Cambridge University Press. $<$ https://doi.org/10.1017/CBO9781316450826>

Lohnstein, H. and Trissler, S. (eds.) 2004. The Syntax and Semantics of the Left Periphery. Berlin-New York: Mouton de Gruyter.

$<$ https://doi.org/10.1515/9783110912111> 
Maraldi, M. 1986. The proleptic accusative: problems of structural analysis. In Calboli G. (ed.). Papers on Grammar II: 87-99. Bologna: Libraria Universitaria.

Molinelli, P. 1999. De + ablative: marca di topic in latino. In Petersmann H. \& Kettemann R. (eds.). Latin vulgaire - latin tardif V (Actes du V $\mathrm{V}^{\mathrm{e}}$ Colloque international sur le latin vulgaire et tardif, Heidelberg, 5-8 septembre 1997), 277-285. Heidelberg: C. Winter.

Oniga, R. 2014. Latin: a linguistic introduction. Oxford: Oxford University Press.

Pinkster, H. 2012. Relative clauses in Latin: some problems of description. In Paula da Cunha Corrêa \& al. (eds). Hyperboreans: Essays in Greek and Latin Poetry, Philosophy, Rhetoric and Linguistics. São Paulo: Humanitas, CAPES.

Pompei, A. 2011. Relative clauses. In Baldi, P. \& Cuzzolin, P. (eds). New Perspectives on Historical Latin Syntax, vol. 4: Complex Sentences, Grammaticalization, Typology, 427-548. Berlin and New York: De Gruyter. $<$ https://doi.org/10.1515/9783110253412.427>

Rizzi, L. 1997. "The Fine Structure of the Left Periphery.” In Liliane Haegeman (ed.). Elements of Grammar: A Handbook of Generative Syntax, 281-337. Dordrecht: Kluwer. $<$ https://doi.org/10.1007/978-94-011-5420-8>

Rizzi, L. (ed.) 2004. The cartography of syntactic structures. vol 2, The structure of $C P$ and IP. New York: Oxford University Press.

Rizzi, L. \& Bocci G. (forthcoming). The left periphery of the clause. In Everaert M., van Riemsdijk H. (eds). The Companion to Syntax, 2nd edition. Oxford: Blackwell.

Rosén, H. 1992. Die Arten der Prolepse im Lateinischen in typologischer Sicht, In Panagl O. \& Krisch Th. (eds.). Latein und Indogermanisch, Akten des Kolloquiums der Indogermanischen Gesellschaft, (Salzburg, 23.-26. September 1986): 243-262. Innsbruck: IBS.

Salvi, G., 2004. La formazione della struttura di frase romanza. Ordine delle parole e clitici dal latino alle lingue romanze antiche. Tübingen: Niemeyer.

Spevak, O. 2011. Constituent Order in Classical Latin Prose. Amsterdam-Philadelphia: John Benjamins.

$<$ https://doi.org/10.1075/slcs.117>

Touratier, C. 1980. La relative, essai de théorie syntaxique (à partir de faits latins, français, allemands, anglais, grecs, hébreux, etc.). Paris: Klincksieck.

Védrenne, P. 2013. Personal subject pronouns and the meta-informative centering of utterances in classical Latin. In Włodarczyk A. \& Włodarczyk H. (eds.). Metainformative Centering in Utterances. Between Semantics and Pragmatics, 285-296. Amsterdam-Philadelphia: John Benjamins.

$<$ https://doi.org/10.1075/slcs.143> 
